\title{
Aspek Gramatikal dan Leksikal pada Lirik Lagu Jangan Rubah Takdirku Karya Andmesh Kamelang
}

\author{
Goziyah $^{{ }^{*}}$, lin Inarotul Uyun ${ }^{2}$, Shella Fabiola ${ }^{3}$ \\ Universitas Muhammadiyah Tangerang 1,2,3 \\ Corresponding email: goziyah1812@gmail.com*
}

\begin{abstract}
The purpose of this research was to describe the grammatical and lexical aspects in the lyrics of the song Jangan Rubah Takdirku by Andmesh Kamelang. The research method uses microstructural methods. The collection technique uses documentation techniques by downloading the song Jangan Rubah Takdirku via Youtube. The main instrument in this research is the researcher who is assisted by a device. Data analysis techniques by means of data reduction, data tabulation, data display, interpretation, and conclusions. Test the validity of the data using membercheck and validation from literary experts. The results showed that the grammatical and lexical aspects in the lyrics of the song Jangan Rubah Takdirku, sung by Andmesh Kamelang, present a deep meaning about the life journey of a person who is full of hard work, loyalty, and hope of love for someone he loves. Grammatical aspects and lexical aspects build up each other so that the song Jangan Rubah Takdirku becomes a song that impresses the listeners. The grammatical aspect found in the song is referencing marked by the presence of the word dia and impingement by the presence of each word. Then, the lexical aspect that was found was repetition which was marked by the presence of the words I want, in each, and I did not, and synomini was marked by the presence of the words weak and shaky.
\end{abstract}

Keywords: grammatical aspects, lexical aspects, and song lyrics

\begin{abstract}
Abstrak
Tujuan penelitian ini mendeskripsikan aspek gramatikal dan aspek leksikal dalam lirik lagu Jangan Rubah Takdirku karya Andmesh Kamelang. Metode penelitian menggunakan metode mikrostruktural. Teknik pengumpulan menggunakan teknik dokumentasi dengan mengunduh lagu Jangan Rubah Takdirku melalui Youtube. Instrumen utama dalam penelitian ini adalah peneliti yang dbantu oleh gawai. Teknik analisis data dengan cara reduksi data, tabulasi data, display data, interpretasi, dan kesimpulan. Uji keabsahan data menggunakan membercheck dan validasi dari pakar sastra. Hasil penelitian menunjukkan Aspek gramatikal dan leksikal dalam lirik lagu Jangan Rubah Takdirku yang dinyanyikan oleh Andmesh Kamelang menghadirkan makna yang mendalam tentang perjalanan hidup seseorang yang penuh kerja keras, kesetiaan, dan pengharapan akan rasa cinta kepada seseorang yang disayanginya. Aspek gramatikal dan aspek leksikal saling membangun sehingga lagu Jangan Rubah Takdirku menjadi lagu yang berkesan pada pendengarnya. Aspek gramatikal yang ditemukan dalam lagu yaitu pengacuan dengan ditandai hadirnya kata dia dan pelesapan dengan
\end{abstract}


ditandai hadirnya kata setiap. Kemudian, aspek leksikal yang ditemukan adalah repetisi dengan ditandai dengan hadirnya kata ku ingin, di setiap, dan ku tak, dan sinomini ditandai dengan hadirnya kata lemah dan goyah.

Kata kunci: aspek gramatikal, aspek leksikal, dan lirik lagu

\section{PENDAHULUAN}

Manusia merupakan makhluk sosial yang tidak bisa hidup sendiri oleh karena itu untuk berinteraksi dengan makhluk yang lain memerlukan suatu alat yang disebut dengan bahasa. Seperti yang diungkapkan oleh Keraf (1997:1) dan Noermanzah (2019) bahwa bahasa berfungsi sebagai alat komunikasi antara anggota masyarakat berupa simbol bunyi yang dihasilkan oleh alat ucap manusia untuk mencapai tujuan tertentu. Akan tetapi, lagu tidak hanya soal irama yang indah, bisa juga dalam hal berbicara dan dan membaca, karena lagu itu irama yang berkesinambungan. Hal tersebut seperti pada pengertian lagu yang dijelaskan oleh Muzakka (2020), bahwa lagu merupakan ragam suara yang berirama dalam bercakap, bernyanyi, membaca dan sebagainya. Lagu merupakan suatu susunan lagu seni nada atau suara dalam urutan, kombinasi dan hubungan temporal (biasanya diiringi dengan alat musik) untuk mengahasilkan susunan lagu musik yang mempunyai kesatuan dan kesinambungan (mengandung irama).

Hasil penelitian ini bertujuan untuk mendeskripsikan (1) bagaimana bentuk kohesi gramatikal pada lirik lagu Jangan Rubah Takdirku yang dinyanyikan oleh Andmesh Kamelang, dan (2) bagaimana bentuk kohesi leksikal pada lirik lagu Jangan Rubah Takdirku yang dinyanyikan Andmesh Kamelang. Analisis aspek gramatikal merupakan sebuah analisis dari segi tata bahasa. Analisis aspek gramatikal meliputi: pengacuan (reference), penggantian (subtitution), pelesapan (ellipsis). Pengacuan (referensi) menurut Sumarlam (2008:29) merupakan salah satu jenis kohesi gramatikal yang berupa satuan lingual yang mendahului atau mengikutinya. Penggantian (subtitution) merupakan proses atau hasil penggantian unsur bahasa oleh unsur lain dalam satuan yang lebih besar untuk memperoleh unsur-unsur pembeda atau untuk menjelaskan suatu struktur tertentu (Kridalaksana,1984:185). Pelesapan (ellipsis) menurut Sumarlam (2008:38) merupakan salah satu jenis kohesi gramatikal yang berupa penghilangan unsur (konstituen) tertentu yang telah disebutkan sebelumnya.

Analisis aspek leksikal wacana menitikberatkan pada segi makna unsur batin sebuah wacana (Dedi \& Cekman, 2018). Analisis aspek leksikal meliputi repetisi (pengulangan), sinonimi (padanan kata), kolokasi (sanding kata), hiponimi (hubungan atas bawah), dan antonimi (lawan kata). Repetisi (pengulangan) menurut Oktafianus (2006:63), repetisi merupakan pemunculan bentuk yang sama yang mengacu ke makna yang sama dalam suatu wacana. Sedangkan menurut Sumarlam (2008:43), repetisi adalah pengulangan satuan lingual (bunyi, suku kata, kata, maupun bagian kalimat) yang dianggap penting untuk memberi tekanan dalam sebuah konteks yang sesuai (Noermanzah, 2020). Sinonimi atau padanan kata merupakan alat kohesi leksikal dalam wacana yang menunjukkan pemakaian lebih dari satu bentuk bahasa yang secara semantik dan memiliki kesamaan atau kemiripan (Sumarlam, 2008:47). Suatu wacana yang dinamis juga sering menempatkan kohesi leksikal secara fleksibel dan variatif dengan mempertentangkan makna yang berlawanan (Oktafianus, 2006:64). Menurut Kusmiarti dkk,. (2020) dalam berkomunikasi sehari-hari, salah satu alat yang paling 
sering digunakan adalah bahasa, baik bahasa lisan maupun bahasa tulis. Bahasa sebagai sarana komunikasi mempunyai fungsi utama sebagai penyampaian pesan atau makna oleh seseorang kepada orang lain dalam masyarakat. Melalui bahasa kita dapat menyatakan secara terbuka segala sesuatu yang tersirat di dalam dada dan pikiran kita (Astiti dkk., 2020). Misalnya seperti seorang penulis buku, mereka akan menuangkan segala seseuatu yang mereka pikirkan ke dalam sebuah tulisan tanpa memikirkan si pembaca, mereka hanya berfokus pada keinginan mereka sendiri. Seorang penulis dapat menungkan pikirannya melalui berbagai media satu diantaranya melalui lirik lagu. Banyak penulis lagu membuat karya-karya mereka berdasarkan perasaan yang sedang mereka alami. Selain berdasarkan pengalaman pribadi ada juga yang berdasarkan lingkungan sekitar mereka, seperti kisah hidup keluarga, saudara, dan teman. Seni tidak bisa terlepas dari kehidupan manusia, sebab seni tumbuh dan berkembang di tengah-tengah kehidupan manusia. Pada dasarnya seni bersumber dari perasaan manusia seperti sedih, senang, marah, kecewa, cinta atau perasaan lainnya yang berhubungan dengan naluri kita masingmasing sebagai manusia. Semua perasaan itu dapat diungkapkan oleh pencipta atau pelaku seni melalui media bunyi, atau suara, gerak, rupa, kata-kata, tingkah laku secara tepat sehingga dapat diterima dan dirasakan oleh pencipta dan pengamat seni. Untuk memahami makna dalam lagu tentu kita perlu memahami hubungan dalam setiap bahasa yang disampaikan, salalah satu cara untuk memahami makna dalam lagu kita bisa melakukannya dengan menganalisis kohesi gramatikal dan leksikal. Untuk itu, pentingnya mengkaji aspek gramatikal dan leksikal pada lirik lagu Jangan Rubah Takdirku yang dinyanyikan oleh Andmesh Kamelang. Dengan memahami aspek gramatikal dan leksikal dapat dijadikan salah satu bahan pembelajaran di sekolah bahwa dalam menuangkan tulisan berupa puisi yang dijadikan lagu perlu memperhatikan aspek gramatikal dan aspek leksikal.

\section{METODE}

Penelitian ini menggunakan pendekatan metode mikrostruktural yang dengan menganalisis kohesi leksikal dan kohesi gramatikal. Bentuk penelitian ini adalah deskriptif kualitatif. Sumber data penelitian ini yaitu lirik lagu Jangan Rubah Takdirku karya Andmesh Kamelang dan sekaligus dinyanyikan oleh Andmesh Kamelang. Sedangkan data penelitian yaitu lirik lagu Jangan Rubah Takdirku karya Andmesh Kamelang yang mengandung aspek gramatikal dan leksikal.

Teknik pengumpulan menggunakan teknik dokumentasi dengan mengunduh lagu Jangan Rubah Takdirku melalui Youtube. Instrumen utama dalam penelitian ini adalah peneliti. Teknik analisis data dengan cara reduksi data, tabulasi data, display data, interpretasi, dan kesimpulan. Uji keabsahan data menggunakan membercheck dan validasi dari pakar sastra.

\section{HASIL}

Aspek gramatikal suatu wacana adalah analisis wacana dari segi bentuk atau struktur lahir wacana. Analisis wacana dari aspek gramatikal meliputi referensi (pengacuan), subtitusi (penyulihan), elipsis (pelesapan). Aspek gramatikal dan aspek leksikal saling membangun sehingga lagu Jangan Rubah Takdirku menjadi lagu yang berkesan pada pendengarnya. Aspek gramatikal yang ditemukan dalam lagu yaitu pengacuan dengan ditandai hadirnya kata dia dan pelesapan dengan ditandai hadirnya kata setiap. Kemudian, aspek leksikal yang ditemukan adalah repetisi dengan ditandai 
dengan hadirnya kata ku ingin, di setiap, dan $k u$ tak, dan sinomini ditandai dengan hadirnya kata lemah dan goyah. Kemudian, aspek leksikal yang ditemukan adalah repetisi (pengulangan) dengan ditemukan kata ku ingin, di setiap, dan ku tak, dan sinomini (padanan kata) ditemukan kata lemah dan goyah.

Berikut data lirik lagu Jangan Rubah Takdirku yang dinyanyikan oleh Andmesh Kamelang yang mengandung aspek gramatikal dan aspek leksikal:

(1) Di setiap doaku di setiap air mataku selalu ada kamu

(2) Di setiap kataku ku sampaikan cinta ini cinta kita

(3) Ku tak akan mundur

(4) Ku tak akan goyah

(5) Meyakinkan kamu

(6) Mencintaiku

(7) Tuhan ku cinta dia

(8) Ku ingin bersamanya

(9) Ku ingin habiskan nafas ini berdua dengannya

(10) Jangan rubah takdirku

(11) Satukanlah hatiku dengan hatinya

(12) Bersama sampai akhir

Dari data lagu Jangan Rubah Takdirku yang dinyanyikan oleh Andmesh Kamelang, diperoleh hasil analisis aspek gramatikal dan aspek leksikal, yaitu:

1. Aspek Gramatikal

a. Pengacuan (referensi) terdapat pada data (1) dan (5) yang ditandai kata kamu.

b. Pelesapan (elipsis) terdapat pada data (1), (2), (3), (4) dan (7) yang ditandai kata setiap yang mengalami pelesapan.

2. Aspek Leksikal

a. Repetisi (pengulangan) terdapat pada data (1), (2), (3), (4), (8) dan (9) yang ditandai dengan hadirnya kata ku ingin, di setiap, dan ku tak.

b. Sinomini (padanan kata) terdapat pada data (5) dan (4) yang ditandai dengan hadirnya kata lemah dan goyah.

\section{PEMBAHASAN}

Aspek gramatikal dan leksikal dalam lirik lagu Jangan Rubah Takdirku karya Andmesh Kamelang menghadirkan makna yang mendalam tentang perjalanan hidup seseorang yang penuh kerja keras, kesetiaan, dan pengharapan akan rasa cintanya kepada seseorang yang disayanginya. Aspek gramatikal dan aspek leksikal saling membangun sehingga lagu Jangan Rubah Takdirku menjadi lagu yang berkesan pada pendengarnya. Hal ini sesuai dengan pendapat Agustina (2016:99) dan Sari \& Setyorini (2018) bahwa wacana, baik dalam bentuk tulis maupun lisan, dalam hal ini wacana lagu dibangun dengan adanya hubungan kohesi gramatikal (hubungan bentuk) dan kohesi leksikal (hubungan makna) antara kalimat sehingga mampu menyampaikan pesan kepada pendengar atau pembacanya. Aspek gramatikal yang ditemukan dalam lagu yaitu pengacuan (referensi) dengan ditemukan kata ditemukan kata dia, pelesapan (ellipsis) dengan ditemukan kata setiap. Untuk lebih jelaskan akan dibahas setiap temuan unsur gramatikal dan unsur leksikal yang terdapat dalam lagu Jangan Rubah Takdirku yang dinyanyikan oleh Andmesh Kamelang sebagai berikut. 


\section{Aspek Leksikal pada Lirik Lagu Jangan Rubah Takdirku}

a. Pengacuan (Referensi)

Analisis kepaduan wacana kohesi gramatikal yang terdapat pada lirik lagu "Jangan Rubah Takdirku" berupa referensi (pengacuan) personal, referensi personal direalisasikan melalui pronomina persona (kata ganti orang), yang meliputi persona pertama (persona I), persona kedua (persona II), dan persona ketiga (persona III), baik tunggal maupun jamak.

Lirik lagu "Jangan Rubah Takdirku" sebagai berikut:

(1) Di setiap doaku di setiap air mataku selalu ada kamu

(5) Meyakinkan kamu

Pada lirik lagu "Jangan Rubah Takdirku" terdapat kata kamu pada data (1) dan (5) merupakan bentuk pronomina persona pertama (persona I) jamak, yang mengarahkan pada setiap manusia yang hidup di dunia.

\section{b. Pelesapan (Elipsis)}

Pelesapan (elipsis) merupakan salah satu jenis kohesi gramatikal yang berupa penghilangan unsur (konstituen) tertentu yang telah disebutkan (Sulaksono, 2019). Unsur yang dilesapkan bisa berupa kata, frasa, klausa, maupun kalimat.

Pada lirik lagu "Jangan Rubah Takdirku" terdapat sebuah pelesapan dalam data berikut:

(1) Di setiap doaku di setiap air mataku selalu ada kamu

(2) Di setiap kataku ku sampaikan cinta ini cinta kita

(3) Ku tak akan mundur

(4) Ku tak akan goyah

(7) Tuhan ku cinta dia

Pada lirik lagu "Jangan Rubah Takdirku" terjadi sebuah pelesapan (elipsis) berupa kata setiap pada data (1) yang mana kata setiap juga terdapat pada data (2).

\section{Aspek Leksikal pada Lirik Lagu Jangan Rubah Takdirku}

Aspek leksikal adalah alat kohesi dalam wacana yang berkaitan dengan hubungan antara unsur dalam wacana sistematis dan bukan secara gramatikal atau bentuk, tetapi secara makna (Sinambela dkk., 2019). Kohesi leksikal yaitu repetisi (pengulangan), sinonimi (padan kata), antonimi (lawan kata), hiponimi (hubungan atas bawah), dan kolokasi (sanding kata).

a. Repetisi (Pengulangan)

Repetisi adalah pengulangan satuan lingual (bunyi, suku kata, kata, maupun bagian kalimat) yang dianggap penting untuk memberi tekanan dalam sebuah konteks yang sesuai (Wijayanti, 2015). Pada lirik lagu "Jangan Rubah Takdirku" terdapat repetisi (pengulangan) berupa repetisi epizeukis. Repetisi epizeukis adalah pengulangan satuan lingual yang dipentingkan beberapa kali secara berturut-turut. Analisis repetisi (pengulangan) pada lirik lagu "Jangan Rubah Takdirku" dalam data berikut.

(1) Di setiap doaku di setiap air mataku selalu ada kamu

(2) Di setiap kataku ku sampaikan cinta ini cinta kita

(3) Ku tak akan mundur

(4) Ku tak akan goyah

(8) Ku ingin bersamanya

(9) $K u$ ingin habiskan nafas ini berdua dengannya 
Pada repitisi epizeukis terdapat pada kata di setiap pada data (1) dan (2), kata Ku tak terdapat pada data (3) dan (4). Kata Ku ingin di ulang pada data (8) dan (9).

b. Sinonimi (Padanan Kata)

Sinonimi atau padanan kata merupakan alat kohesi leksikal dalam wacana yang menunjukkan pemakaian lebihdari satu bentuk bahasa yang secara semantik memiliki kesamaan atau kemiripan (Widayati, 2018). Analisis sinonimi pada lirik lagu "Jangan Rubah Takdirku" dalam data berikut.

(5) Ku tak akan mundur

(4) Ku tak akan goyah

Pada lirik lagu "Jangan Rubah Takdirku" terdapat sinonimi pada kata Mundur pada data (5) memiliki makna yang sepadan dengan kata Goyah yang terdapat pada data (4) sehingga ke dua data tersebut memiliki kesepadanan kata.

\section{KESIMPULAN DAN SARAN}

Berdasarkan hasil dan pembahasandapat disimpulkan bahwa aspek gramatikal dan leksikal dalam lirik lagu Jangan Rubah Takdirku karya Andmesh Kamelang menghadirkan makna yang mendalam tentang perjalanan hidup seseorang yang penuh kerja keras, kesetiaan, dan pengharapan akan rasa cinta kepada seseorang yang disayanginya. Aspek gramatikal dan aspek leksikal saling membangun sehingga lagu Jangan Rubah Takdirku menjadi lagu yang berkesan pada pendengarnya. Aspek gramatikal yang ditemukan dalam lagu yaitu pengacuan dengan ditandai hadirnya kata dia dan pelesapan dengan ditandai hadirnya kata setiap. Kemudian, aspek leksikal yang ditemukan adalah repetisi dengan ditandai dengan hadirnya kata $k u$ ingin, di setiap, dan ku tak, dan sinomini ditandai dengan hadirnya kata lemah dan goyah. Dari hasil penelitian ini, dapat dijadikan bahan pembelajaran sastra Indonesia di sekolah, terutama ketika menyusun puisi bisa mencontoh aspek gramatikal dan leksikal yang dihadirkan dalam lagu Jangan Rubah Takdirku.

\section{DAFTAR PUSTAKA}

Agustina, R. (2016). Aspek Leksikal dan Gramatikal Pada Lirik Lagu Jika Karya Melly Goeslow. BAHASTRA, 36(1), 97. doi:10.26555/bahastra.v36i1.5061

Astiti, M. S., Wardarita, R., \& Fitriani, Y. (2020). The Preservation of Balinese Spoken Language at the Ngaben and Potong Gigi Event. Jadila: Journal of Development and Innovation in Language and Literature Education, 1(2), 139-149. Retrieved from https://ejournal.karinosseff.org/index.php/jadila/article/view/42

Dedi, D., \& Cekman, C. (2018). Kohesi Leksikal dalam Acara Berasan Masyarakat Sindang Kelingi Musi Rawas. Silampari Bisa: Jurnal Penelitian Pendidikan Bahasa Indonesia, Daerah, dan Asing, 1(1), 66-83. doi:10.31540/silamparibisa.v1i1.15

Keraf, G. (1997). Komposisi. Flores: Nusa Indah.

Kridalaksana, H. (1984). Kamus Linguistik. Jakarta: Gramedia. 
Kusmiarti, R., Yuniati, I., \& Noermanzah. (2020). Improving Student Communication Skills In Learning Indonesian Language Through Collaborative Learning. Retrieved from osf.io/9km3u. International Journal of Scientific and Technology Research, 9(1).

Muzakka, M. (2020). Nilai-Nilai Profetik dalam Dua Lirik Lagu Karya Rhoma Irama Kajian terhadap Lirik Lagu "Akhlak" dan "Virus Corona." Nusa: Jurnal IImu Bahasa dan Sastra, 15(1), 13-22. doi:10.14710/nusa.15.1.13-22

Noermanzah, N. (2019). Bahasa sebagai Alat Komunikasi, Citra Pikiran, dan Kepribadian. Seminar Nasional Pendidikan Bahasa dan Sastra, Prosiding Seminar Nasional Bulan Bahasa (Semiba), 307, https://ejournal.unib.ac.id/index.php/semiba/article/view/11151/5537

Noermanzah, N. (2020). Pemilihan Perangkat Retorika pada Pidato Presiden Republik Indonesia dalam Mempromosikan Kebijakan Pemerintah dalam Bidang Pendidikan. Diglosia: Jurnal Pendidikan, Kebahasaan, dan Kesusastraan Indonesia, 4(2). http://jurnal.unma.ac.id/index.php/dl/article/view/2351

Oktafianus. (2006). Analisis Wacana Lintas Bahasa. Padang: Andalas University Press.

Sari, I. P., \& Setyorini, R. (2018). Aspek Gramatikal dan Leksikal Pada Lirik Lagu "Aku Cinta Allah" Group Band Wali. SeBaSa, 1(2), 129. doi:10.29408/sbs.v1i2.1040

Sinambela, K., Simanjuntak, T., \& Telaumbanua, S. (2019). Aspek Kohesi Gramatikal dan Leksikal pada Karangan Eksposisi Kelas X SMA Negeri 1 Laguboti Kabupaten Toba Samosir T.A 2018|2019. Jurnal Genre (Bahasa, Sastra, dan Pembelajarannya), 1(1), 9. doi:10.26555/jg.v1i1.1054

Sulaksono, D. (2019). Analisis Aspek Gramatikal dan Leksikal Iklan Kecik dalam Surat Kabar Solopos. JISABDA: Jurnal IImiah Sastra dan Bahasa Daerah, serta Pengajarannya, 1(2), 13. doi:10.26877/jisabda.v1i2.4740

Sumarlam. Ed. (2008). Teori dan Praktik Analisis Wacana. Surakarta: Pustaka Cakra.

Widayati, S. (2018). Analisis Wacana Cerpen "Tinggal Matanya Berkedip-kedip" Karya Ahmad Tinjauan Aspek Sosial Budaya serta Penanda Kohesi Gramatikal dan Leksikal. Edukasi Lingua Sastra, 15(2), 73-88. doi:10.47637/elsa.v15i2.69

Wijayanti, S. H. (2015). Ketaksaan Gramatikal dan Leksikal dalam Bahasa Indonesia. Diksi, 10(2). doi:10.21831/diksi.v10i2.6966 